УДК 502.74: 595.7

DOI 10.18413/2658-3453-2020-2-34-43

\title{
НОВЫЕ НАХОДКИ РЕДКИХ НАСЕКОМЫХ В СЕВЕРО-ВОСТОЧНОЙ ЧАСТИ ВОРОНЕЖСКОЙ ОБЛАСТИ
}

\author{
NEW RECORDS OF RARE INSECTS IN THE NORTH-EASTERN PART \\ OF VORONEZH OBLAST
}

\author{
А.Н. Володченко \\ A.N. Volodchenko \\ Балашовский институт Саратовского национального исследовательского государственного \\ университета имени Н.Г. Чернышевского, \\ Россия, 412300, Саратовская обл., г. Балашов, ул. Карла Маркса, 29 \\ Balashov Institute of Saratov State University, \\ 29 Karl Marx St, Balashov, Saratov oblast, 412300, Russia \\ E-mail: kimixla@mail.ru
}

\begin{abstract}
Аннотация
В статье приводятся новые данные о распространении в северо-восточной части региона 45-ти видов насекомых, внесенных в Красную книгу Воронежской области. Для 41-го вида новые местообитания выявлены на основании исследований, проведенных в 2013-2018 гг., для 4-х видов - Lymexilon navale (Linnaeus, 1758), Anaerea carcharias (Linnaeus, 1758), Chlorophus sartor (Muller, 1766), Mesosa curculionoides (Linnaeus, 1761) приводятся только литературные сведения, не вошедшие в последнее издание Красной книги области. Современными данными подтверждается обитание Rosalia alpina (Linnaeus, 1758) на территории области. Приведены сведения об обитании дубовой златки Eurythyrea quercus (Herbst, 1780) в Воронежской области. Рассмотрены особенности распределения охраняемых видов по экосистемам района исследования и по территории региона.

Abstract

This paper presented new data on the distribution of the protected species occurring in nordeastern parts of Voronezh oblast (Russia). The material for this investigation was collected from the various habitats from 2013 to 2019. The study areas were Borisoglebsky and Povorinsky districtes. The main sampling and collection method was to use the traditional approach of visual collecting and sweeping vegetation with an entomological net. Additional methods used Pitfall traps and Malaise traps. As a result of study were recorded 45 species rare insect from 4 orders: Mantoptera (1 species), Orthoptera (1 species), Hymenoptera (5 species), Coleoptera (38 species). Moreover, the occurrence of one specimens of alpine longhorn beetle Rosalia alpina (Linnaeus, 1758) from Voronezh oblast. This is the first certain record of this species for 50 years. This new record is of high conservation value, since this species is included by Red List the Russain Federation and the European Union. Information is given on the habitat of Eurythyrea quercus (Herbst, 1780) in the Voronezh oblast. Presens data confirm the importance of ecosystems valley of Khopyor River for conservation rare and endangered species.
\end{abstract}

Ключевые слова: насекомые, редкие виды, новые находки, Красная книга, Воронежская область, лесостепные экосистемы, сохранение биоразнообразия.

Keywords: insects, rare species, new record, Red Book, Voronezh oblast, forest-steppe ecosystem, biodiversity conservation.

\section{Введение}

Охрана биологического разнообразия является важной задачей охраны природы, направленной на поддержание устойчивости природных и антропогенно трансформированных сообществ. Большое значение в сохранении малочисленных и 
уязвимых видов имеет ведение Красных книг разного уровня, в том числе региональных, оценивающих местные особенности состояния флоры и фауны.

Следствием значительных хозяйственных преобразований территории Воронежской области стала фрагментация и сокращение размеров среды обитания многих видов живых организмов, что в свою очередь привело к сокращению их численности. Красная книга области включает значительное число насекомых: в первое издание было занесено 264 вида, во второе - 261 вид [Красная книга ..., 2011, 2018]. Хотя наблюдается незначительное сокращение количества видов, нуждающихся в охране. Состояние популяций многих охраняемых видов остается нестабильным. Поэтому продолжает оставаться актуальным изучение распространения редких видов на территории региона и проведение мониторинга их популяционных показателей. Для района исследований приводится много указаний в литературе об обитании редких видов, датируемых серединой XX в., но сведения по современному состоянию популяций и распространению редких видов немногочисленны [Володченко, 2010, 2016; Прокин, 2016]. В предлагаемой статье приведены новые данные о распространении охраняемых видов насекомых в северо-восточной части Воронежской области.

\section{Материал и методы исследования}

Исследование проводилось в северо-восточной части Воронежской области на территории Борисоглебского городского округа и Поворинского района. Территория исследования располагается на юго-востоке Окско-Донской равнины, отличается выровненным рельефом с незначительными перепадами высот. Район исследования относится к южной лесостепи и расположен вблизи границы со степной зоной. Исконная растительность здесь была представлена широколиственными лесами и разнотравнолуговыми степями, в настоящее время леса сохранились по речным долинам, а луга преимущественно по склонам балок и малоценным для сельского хозяйства землям.

Материал собирался с 2013 по 2019 гг. во время краткосрочных экспедиций в различные местности и экосистемы, преимущественно обследовались лесные сообщества. Основными методами сбора являлись кошение энтомологическим сачком по растительности, визуальное обследование цветущих растений, стволов и ветвей растений, также использовались почвенные ловушки и модифицированные ловушки Малеза, размещающиеся на стволах деревьев. Обнаруженные визуально особи редких видов по возможности не беспокоились, насекомые, пойманные живыми в сачок или ловушки, после идентификации отпускались. Кроме этого, в настоящей статье приводятся материалы публикации Г.В. Линдемана [1964], данные которой не отражены в последнем издании Красной книги Воронежской области, но указанная работа содержит интересные сведения по охраняемым насекомым на территории Теллермановского леса.

Далее приводится список видов насекомых, включенных в Красную книгу Воронежской области и отмеченных на исследованной территории северо-восточной части региона. Порядок, названия и статус видов указываются согласно Красной книге Воронежской области. Подробно приведена характеристика авторского материала. В качестве примечаний приведены данные, дополняющие информацию из Красной книги Воронежской области.

\section{Результаты исследования}

Аннотированный список видов насекомых, занесенных Красную книгу Воронежской области [2018] и отмеченных в северо-восточной части региона.

Отряд Богомолы - Mantoptera

1. Богомол обыкновенный - Mantis religiosa (Linnaeus, 1758)

Природоохранный статус. Категория 3 - редкий вид. 
Материал. Борисоглебский городской округ: 1.8 км В с. Третьяки, 51²1'37.8" с. ш. 42³0'50" в. д., псаммофитная степь, на степной растительности, 1.07.2019 (2 экз.); 7 км

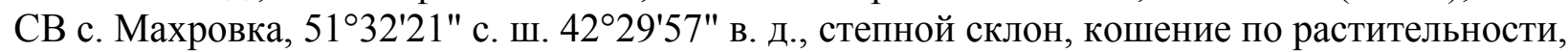

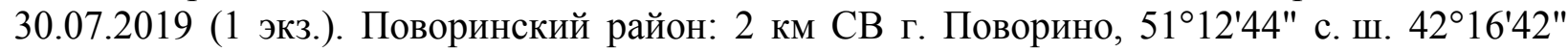
в. д., псаммофитная степь, кошение по растительности, 22.07.2018 (2 экз.), там же, кошение по растительности, 19.07.2019 (1 экз.); 3.5 км В с. Самодуровка, 51 $12^{\prime} 17^{\prime \prime}$ с. ш. 4224'38" в. Д., псаммофитная степь, на растительности, 12.08.2019 (1 экз.).

Примечание. Ранее по территории Воронежской области проводилась северная граница ареала [Бей-Биенко, 1964]. Но в последнее десятилетие вид значительно расширил свой ареал на север Восточной Европы и Европейской части России [Shcherbakov, Savitsky, 2015; Zieliński et al., 2018].

\section{Отряд Прямокрылые - Orthoptera}

2. Дыбка степная - Saga pedo (Pallas, 1771)

Природоохранный статус. Категория 1 - вид, находящийся под угрозой исчезновения.

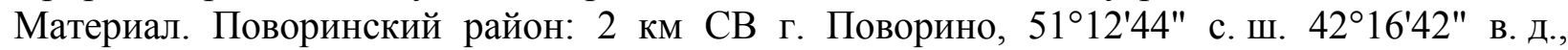
псаммофитная степь, кошение по растительности, 22.07.2018 (2 экз.).

Примечание. Вид включен в Красную книгу России [2001]. Местообитания вида в настоящее время относятся к антропогенным изолятам [Присный, 2003]. В связи с партеногенетическим способом размножения, численность вида не определяется факторами, зависящими от популяционных показателей и успеха встречи полов.

Отряд Перепончатокрылые - Hymenoptera

3. Литург - Lithurgus cornutus fuscipennis (Lepeletier 1841)

Природоохранный статус. Категория 3 - редкий вид.

Материал. Поворинский район: 3.5 км В с. Самодуровка, 51¹2'17" с. ш. 42²4'38" в. д., псаммофитная степь, на цветах сложноцветных, кошение по цветущим растениям, 12.08.2019 (3 экз.).

Примечание. Первое указание для восточной части области.

4. Бембекс носатый - Bembix rostrata (Linnaeus, 1758)

Природоохранный статус. Категория 2 - вид, сокращающийся в численности.

Материал. Борисоглебский городской окр.: 1.6 км СВ с. Губари, 51³1'38" с. ш. 42³5'2" в. д., опушка соснового леса на песках, 30.07.2019 (2 экз.).

Примечание. Первое указание для восточной части области. Лимитирующим фактором является недостаток подходящих мест обитания.

5. Сколия степная - Scolia hirta (Schrank, 1781)

Природоохранный статус. Категория 2 - вид, сокращающийся в численности.

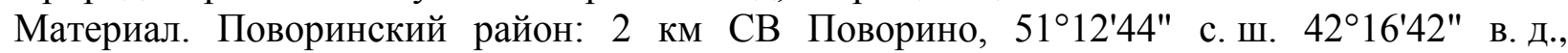
псаммофитная степь, на растениях рода Allium, 01.07.2018 (1 + ).

Примечание. Численность вида определяется численностью крупных пластинчатоусых, на которых проходят развитие личинки.

6. Сколия гигантская - Megascolia maculata (Drury, 1773)

Природоохранный статус. Категория 3 - редкий вид.

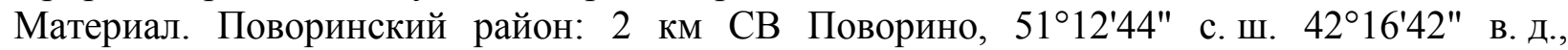
псаммофитная степь, 22.07.2018 (1 ), там же, 1.07.2019 (1 q).

Примечание. Численность вида определяется численностью крупных пластинчатоусых, на которых проходят развитие личинки.

7. Крупный парнопес - Parnopes grandior (Pallas, 1771)

Природоохранный статус. Категория 2 - вид, сокращающийся в численности.

Материал. Борисоглебский городской округ: 1.6 км СВ с. Губари, 51³1'38" с. ш. 42³5'2" в. д., опушка соснового леса на песках, 25.06.2019 (1 экз.).

Примечание. Вид включен в Красную книгу России. Первое указание для востока области. Численность и распространение вида зависит от хозяина - ос рода Bembix. 


\section{Отряд Жесткокрылые - Coleoptera}

8. Блетиса многоточечная - Blethisa multipunctata (Linnaeus, 1758)

Природоохранный статус. Категория 1 - вид, находящийся под угрозой исчезновения.

Материал. Борисоглебский городской округ: 1.6 км СВ с. Губари, 51³1'38" с. ш. 42³5'2" в. д., берег пойменного озера, 12.05.2018 (1 экз.).

Примечание. Первое указание для востока области. Недавно найден в Балашовском районе Саратовской области на ООПТ «Озеро Рассказань» [Сажнев и др., 2018], которое расположено в 6 км от обнаруженного местонахождения вида. Выявленными местообитаниями в Прихоперье являются пойменные озера с густыми прибрежными зарослями осок.

9. Красотел исследователь - Calosoma investigator (Illiger, 1798)

Природоохранный статус. Категория 3 - редкий вид.

Материал. Поворинский район: 1.2 км СВ с. Пески, 51¹7'16" с. ш. 42²9'16" в. д., пойма p. Белозерка, пойменная дубрава 16.06.2018 (1 экз.).

Примечание. Первое указание для восточной части области.

10. Жужелица золотоямчатая - Carabus clathratus Linnaeus, 1761

Природоохранный статус. Категория 3 - редкий вид.

Материал. Поворинский район: 3.4 км С г. Поворино, 51¹4'21" с. ш. 42¹4'9" в. д., пойменный лес, почвенная ловушка, 17-30.05.2016 (3 экз.).

11. Зубастая дрипта - Drypta dentata (Rossi, 1790)

Природоохранный статус. Категория 1 - вид, находящийся под угрозой исчезновения.

Материал. Борисоглебский городской округ: 1.6 км СВ с. Губари, 51³1'38" с. ш. 42³5'2" в. д., берег пойменного озера, 12.05.2018 (1 экз.).

12. Карапузик-плоскушка - Hololepta plana (Sulzer, 1776)

Природоохранный статус. Категория 3 - редкий вид.

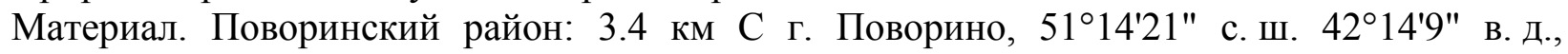
пойменный лес, под корой осины, 17.05.2016 (1 экз.); Борисоглебский городской округ:

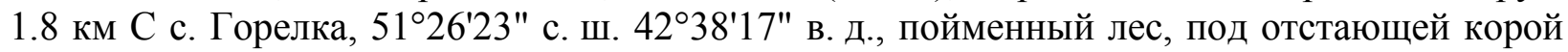
осины, 23.08.2019 (1 экз.).

13. Жук-олень - Lucanus cervus (Linnaeus, 1758)

Природоохранный статус. Категория 5 - восстанавливающийся вид.

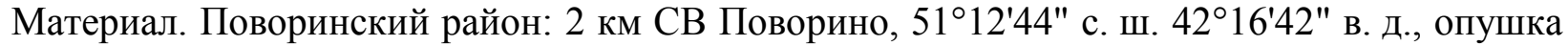

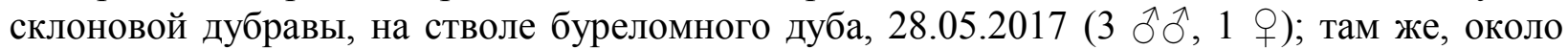

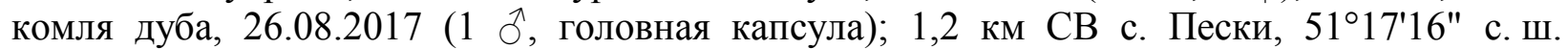
$42^{\circ} 29^{\prime} 16^{\prime \prime}$ в. Д., пойма р. Белозерка, пойменная дубрава, на лету и на стволе дуба, 16.06.2018 (3 ふふふ).

Примечание. Вид включен в Красную книгу России [2001].

14. Носорожек малый - Sinodendron cylindricum (Linnaeus, 1758)

Природоохранный статус. Категория 2 - вид, сокращающийся в численности.

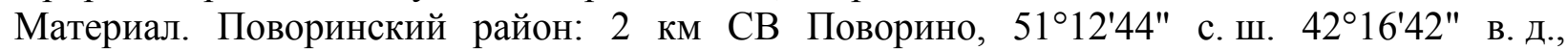
пойменный лес, стволовая ловушка на гниющей осине, 14.06.-1.07.2019 (1 ).

15. Бронзовка зеленая большая - Cetonischema aeruginosa (Drury, 1770)

Природоохранный статус. Категория 2 - вид, сокращающийся в численности.

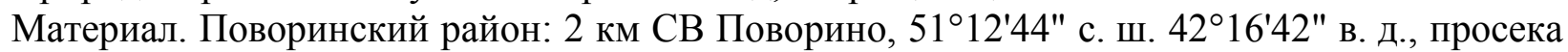
в пойменном лесу, лов в воздухе, 1.07.2019 (1 экз.).

Примечание. Вид включен в Красную книгу России [2001]. Численность и местообитания данного вида бронзовок выявить трудно, так как имаго летают в верхних частях крон деревьев, откуда редко спускаются вниз [Plewa et al., 2014].

16. Восковик изменчивый - Gnorimus variabilis (Linnaeus, 1758)

Природоохранный статус. Категория 1 - вид, находящийся под угрозой исчезновения.

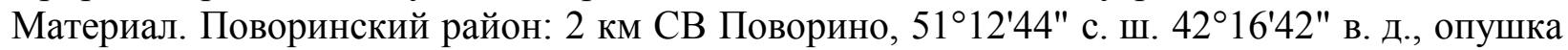
склоновой дубравы, на стволе буреломного дуба, 28.05.2017 (1 экз.). 
17. Капюшонник капуцин - Bostrychus capucinus (Linnaeus, 1758)

Природоохранный статус. Категория 3 - редкий вид.

Материал. Поворинский район: 2 км СВ Поворино, 51²12'44" с. ш. $42^{\circ} 16^{\prime} 42^{\prime \prime}$ в. д., опушка склоновой дубравы, на лежащем стволе дуба, 18.05 .2019 (2 $\widehat{\jmath}, 2$ o

Примечание. Отмечен в Теллермановском лесничестве [Линдеман, 1964].

18. Капюшонник изменчивый - Lichenophanes varius (Illiger, 1801)

Природоохранный статус. Категория 1 - вид, находящийся под угрозой исчезновения.

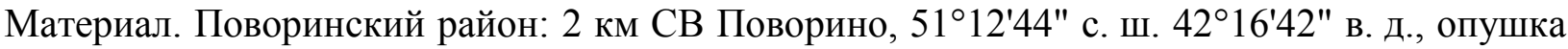
склоновой дубравы, стволовая ловушка на дубовых бревнах, 18.06.-1.07.2019 (2 $\hat{\jmath} \widehat{\jmath}, 2$ 우우).

Примечание. Отмечен в Теллермановском лесничестве [Линдеман, 1964].

19. Пестряк пестрый - Clerus mutillarius Fabricius, 1775

Природоохранный статус. Категория 1 - вид, находящийся под угрозой исчезновения.

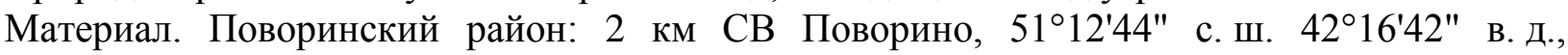
склоновая дубрава, на лежащем стволе дуба, 18.05 .2019 (2 экз.); там же, стволовая ловушка на дубе, 1.07.2019 (12 экз.); там же, стволовая ловушка на бревнах вяза, липы и дуба, 1.07.2019 (8 экз.).

Примечание. Первое указание для востока области.

20. Сверлило дубовое - Lymexilon navale (Linnaeus, 1758)

Природоохранный статус. Категория 3 - редкий вид.

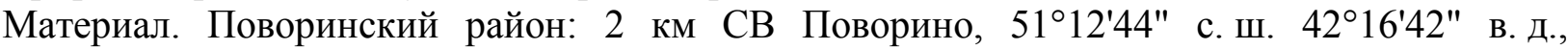
склоновая дубрава, стволовая ловушка на дубе, 8-18.05.2018 (1 экз.).

Примечание. Отмечен в Теллермановском лесничестве [Линдеман, 1964].

21. Щелкун крестоносец - Selatosomus cruciatus (Linnaeus, 1758)

Природоохранный статус. Категория 3 - редкий вид.

Материал. Поворинский район: 4.2 км С3 с. Рождественское, $51^{\circ} 15^{\prime} 36^{\prime \prime}$ с. ш. 4207'7" в. д., опушка пойменной дубравы, кошение по растительности, 28.05.2017 (1 экз.).

Примечание. Учитывая материалы, собранные автором в граничащих районах Саратовской области, возможно предположить, что на исследуемой территории данный вид имеет трехлетний цикл развития, так как все находки сделаны в 2011, 2014, 2017 гг.

22. Златка бронзовая дубовая - Chrysobothris affinis (Fabricius, 1794)

Природоохранный статус. Категория 3 - редкий вид.

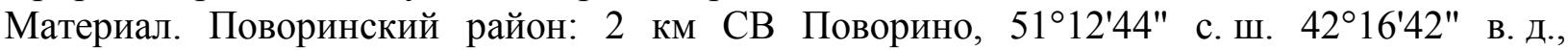
склоновая дубрава, стволовая ловушка на бревнах липы и дуба, 18.05.-1.07.2019 (8 экз.);

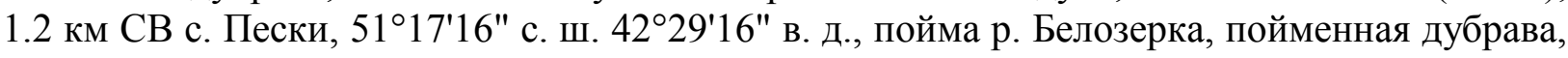
на стволе дуба, 16.06.2018 (6 экз.).

Примечание. Отмечен в Теллермановском лесничестве [Линдеман, 1964].

23. Златка липовая - Lamprodila rutilans (Fabricius, 1777)

Природоохранный статус. Категория 1 - вид, находящийся под угрозой исчезновения.

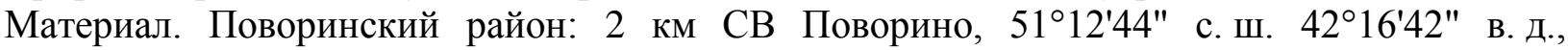
склоновая дубрава, стволовая ловушка на бревнах липы и дуба, 18.05.-1.07.2019 (1 экз.).

Примечание. Отмечен в Теллермановском лесничестве [Линдеман, 1964].

24. Златка синяя сосновая - Melanophila cyanea (Fabricius, 1775)

Природоохранный статус. Категория 1 - вид, находящийся под угрозой исчезновения.

Материал. Борисоглебский городской округ: 3.5 км ЮВ с. Макашевка, 51²7'57" с. ш. 42³7'59" в. д., сосновый лес, на стволе сосны 30.07.2019 (2 экз.).

25. Плоскотелка красная - Cucujus cinnaberinus (Scopoli, 1763)

Природоохранный статус. Категория 1 - вид, находящийся под угрозой исчезновения.

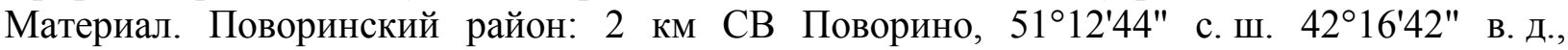
склоновая дубрава, на стволе осины, 20.05 .2016 (1 экз.); 4.2 км С3 с. Рождественское, $51^{\circ} 15 ' 36 "$ с. ш. $42^{\circ} 07^{\prime} 7 "$ в. д., опушка пойменной дубравы, под корой осины, 18.05.2018 (1 экз.). 
26. Тенелюб четырехпятнистый - Dircaea quadriguttata (Paykull, 1798)

Природоохранный статус. Категория 3 - редкий вид.

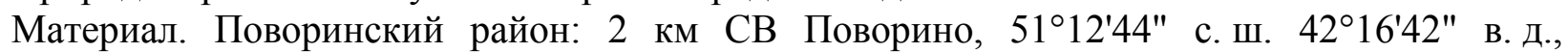
склоновая дубрава, на стволе осины, 18.05.-1.07.2019 (2 экз.).

Примечание. Первое указание для востока области.

27. Тенелюб черный - Melandrya dubia (Schaller, 1783)

Природоохранный статус. Категория 1 - вид, находящийся под угрозой исчезновения.

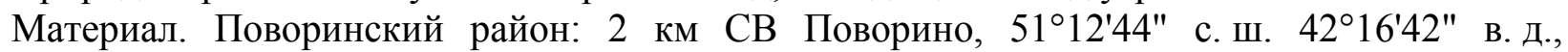
склоновая дубрава, на стволе осины, 18.05.-1.07.2019 (3 экз.).

Примечание. Отмечен в Теллермановском лесничестве. Среди кормовых пород приводятся дуб, ольха, береза и осина, черемуха, лещина и клен остролистный [Линдеман, 1964].

28. Пыльцеед грибной желтоногий - Mycetochara flavipes (Fabricius, 1792)

Природоохранный статус. Категория 3 - редкий вид.

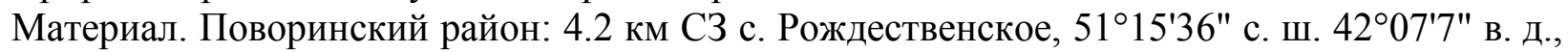
опушка пойменной дубравы, на стволе осины, 18.05 .2018 (1 экз.); 2 км СВ Поворино,

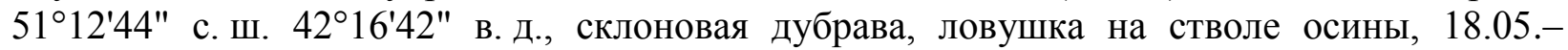
1.07.2019 (1 экз.).

Примечание. Первое указание для востока области.

29. Пыльцеед усачевидный - Pseudocistela ceramboides (Linnaeus, 1758)

Природоохранный статус. Категория 1 - вид, находящийся под угрозой исчезновения.

Материал. Поворинский район: 4.2 км С3 с. Рождественское, 51¹5'36" с. ш. 4207'7" в. Д., опушка пойменной дубравы, на цветах короставника полевого (Knautia arvensis), 18.05.2018 (1 экз.).

30. Акимерус шеффера - Akimerus schaefferi (Laicharting, 1784)

Природоохранный статус. Категория 1 - вид, находящийся под угрозой исчезновения.

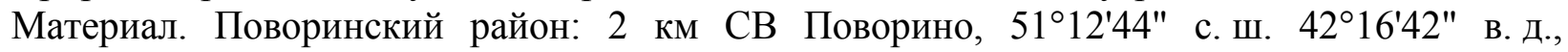
склоновая дубрава, на стволе мертвого дуба, 18.05.-1.07.2019 (1 экз.).

Примечание. Отмечен в Теллермановском лесничестве [Линдеман, 1964]. На востоке Воронежской области вид находится вблизи восточной границы своего ареала [Данилевский, 2014]. Более восточные находки известны из Саратовской области [Горшкова, Володченко, 2016].

31. Скрипун большой осиновый - Anaerea carcharias (Linnaeus, 1758)

Природоохранный статус. Категория 3 - редкий вид.

Примечание. Единственная находка на востоке области - в Теллермановском лесничестве [Линдеман, 1964].

32. Усач малый дубовый - Cerambyx scopolii Fuessly, 1775

Природоохранный статус. Категория 1 - вид, находящийся под угрозой исчезновения.

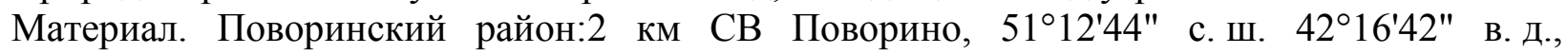
склоновая дубрава, на срубленных стволах дуба, 20.05 .2018 (4 экз.); там же стволовая ловушка на бревнах вяза, 18.05.-1.07.2019 (8 экз.); там же, стволовая ловушка на дубовом пне, 18.05.-1.07.2019 (2 экз.); там же, стволовая ловушка на свежем ольховом пне, 18.05.1.07.2019 (5 экз.); 1.2 км СВ с. Пески, 51¹7'16" с. ш. 42²9'16" в. д., пойма р. Белозерка, пойменная дубрава, на стволе дуба, 16.06.2018 (4 экз.).

Примечание. Отмечен в Теллермановском лесничестве, на различных лиственных деревьях [Линдеман, 1964].

33. Клит малый фигурный - Chlorophus sartor (Muller, 1766)

Природоохранный статус. Категория 1 - вид, находящийся под угрозой исчезновения.

Примечание. Отмечен в Теллермановском лесничестве [Линдеман, 1964].

34. Лептура красногрудая - Macroleptura thoracica (Creutzer, 1799)

Природоохранный статус. Категория 1 - вид, находящийся под угрозой исчезновения. 
Материал. Борисоглебский городской округ: 2 км 3 с. Горелки, 51²4'37" с. ш. 42³6'59" в. д., Балка Живая, на стволе гнилой березы, 30.07.2019 (1 экз.).

Примечание. Отмечен в Теллермановском лесничестве, на березе, осине, клене остролистном, вязе [Линдеман, 1964].

35. Усач долгоносиковый глазчатый - Mesosa curculionoides (Linnaeus, 1761)

Природоохранный статус. Категория 3 - редкий вид.

Примечание. Отмечен в Теллермановском лесничестве [Линдеман, 1964].

36. Большой коротконадкрылый усач - Necydalis major Linnaeus, 1758

Природоохранный статус. Категория 3 - редкий вид.

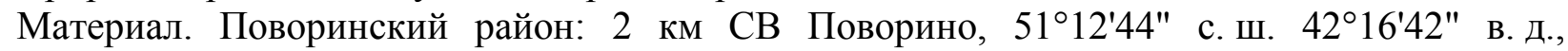
склоновая дубрава, куколка в древесине дубового остолопа, 20.05.2018 (. экз.)

Примечание. Отмечен в Теллермановском лесничестве, на различных лиственных деревьях [Линдеман, 1964].

37. Усач-краснокрыл Келлера - Purpuricenus kaehleri (Linnaeus, 1758)

Природоохранный статус. Категория 3 - редкий вид.

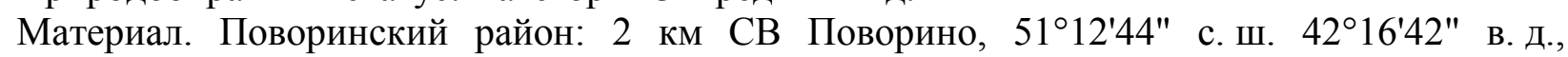
склоновая дубрава, на срубленном стволе дуба, 20.05.2018 (1 экз.).

Примечание. Отмечен в Теллермановском лесничестве [Линдеман, 1964].

38. Рагий пёстрый - Rhagium sycophanta (Schrank, 1781)

Природоохранный статус. Категория 3 - редкий вид.

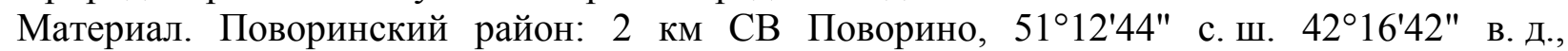
склоновая дубрава, на срубленном стволе дуба, 20.05.2018 (1 экз.).

Примечание. Отмечен в Теллермановском лесничестве [Линдеман, 1964].

39. Усач двуцветный - Rhamnusium bicolor (Schrank, 1781)

Природоохранный статус. Категория 1 - вид, находящийся под угрозой исчезновения.

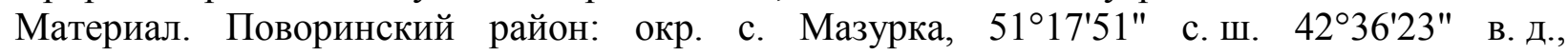
придорожная лесополоса, на осине, 18.06.2019 (1 экз.).

Примечание. Отмечен в Теллермановском лесничестве, развитие на дубе [Линдеман, 1964].

40. Усач большой кленовый - Rhopalopus clavipes (Fabricius, 1775)

Природоохранный статус. Категория 3 - редкий вид.

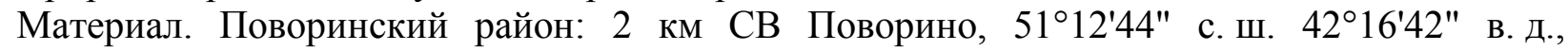
склоновая дубрава, на срубленном стволе дуба, 20.05.2018 (1 экз.).

Примечание. Отмечен в Теллермановском лесничестве, развитие на вязе, лещине, боярышнике, груше, разных видах клена [Линдеман, 1964].

41. Усач альпийский - Rosalia alpina (Linnaeus, 1758)

Природоохранный статус. Категория 0 - вероятно, исчезнувший вид, не отмечался более 25 лет.

Материал. Борисоглебский городской округ: 1.6 км СВ с. Ульяновка, 51¹7'47" с. ш. 4201'36" в. д., на стволе вяза, 16.06.2013 (1 экз.).

Примечание. Вид включен в Красную книгу России [2001]. Отмечен в Теллермановском лесничестве, на вязе и клене остролистном [Линдеман, 1964]. Вид находится вблизи юговосточной границы распространения [Красная книга ..., 2018].

42. Стенокорус меридианальный - Stenocorus meridianus (Linnaeus, 1758)

Природоохранный статус. Категория 1 - вид, находящийся под угрозой исчезновения.

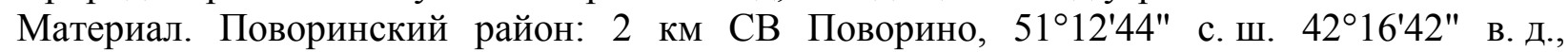
склоновая дубрава, стволовая ловушка на стволе дуба, 20.05.2018 (1 экз.).

Примечание. Отмечен в Теллермановском лесничестве [Линдеман, 1964].

43. Стенокорус дубовый - Stenocorus quercus (Gotz, 1783)

Природоохранный статус. Категория 1 - вид, находящийся под угрозой исчезновения.

Примечание. Отмечен в Теллермановском лесничестве [Линдеман, 1964]. 
44. Ложнослоник большой - Platyrrhinus resinosus (Scopoli, 1763)

Природоохранный статус. Категория 1 - вид, находящийся под угрозой исчезновения.

Материал. Борисоглебский городской округ: 1.6 км СВ с. Ульяновка, 51¹7'47" с. ш. 4201'36" в. д., на пне дуба, 16.06.2013 (1 экз.). Поворинский район: 2 км СВ Поворино, $51^{\circ} 12^{\prime} 44^{\prime \prime}$ с. ш. $42^{\circ} 16^{\prime} 42^{\prime \prime}$ в. д., склоновая дубрава, на срубленном стволе дуба, 18.05.2019 (1 экз.).

Примечание. Отмечен в Теллермановском лесничестве [Линдеман, 1964].

45. Ложнослоник беловатый - Platystomus albinus (Linnaeus, 1758)

Природоохранный статус. Категория 3 - редкий вид.

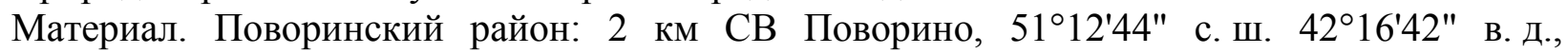
склоновая дубрава, на ветвях буреломного дуба, 20.05.2018 (1 экз.).

Примечание. Отмечен в Теллермановском лесничестве [Линдеман, 1964].

\section{Заключение}

По итогам исследований выявлены новые местообитания в северо-восточной части Воронежской области 45 видов охраняемых насекомых из отрядов Богомолы (1 вид), Прямокрылые (1 вид), Перепончатокрылые (5 видов) и Жесткокрылые (38 видов). Виды L. navale, A. carcharias, Ch. sartor, M. curculionoides с исследуемой территории известны только по литературным указаниям середины прошлого века, однако с большой долей вероятности их популяции сохранились и до настоящего времени.

Важной является первая за длительный срок находка альпийского усача (R. alpina), охраняющегося на территории России и Европы [Nieto, Alexander, 2010; Ильяшенко и др., 2018]. Также интересным является указание на обитание дубовой златки E. quercus в Теллермановском лесу [Арнольди, 1953; Линдеман, 1964]. Этот вид рекомендован для внесения в новое издание Красной книги России [Nieto, Alexander, 2010; Ильяшенко и др., 2018].

Приведенные материалы показывают высокую роль лесных сообществ, расположенных в долинах рек Хопер и Ворона, для сохранения разнообразия многих редких видов ксилофильных насекомых, некоторые из которых имеют высокий охранный статус. Расположенный здесь государственный природный заповедник «Хоперский» и прилегающий к нему Теллермановский лесной массив сохраняют на своей территории значительную часть разнообразия редких ксилофильных насекомых. С выходами свободных или закрепленных песков долины реки Хопер связано обитание таких видов, как B. rostrata, S. hirta, M. maculata, P. grandior. Таким образом, экосистемы долин рек Хопер и Ворона составляют важный элемент экологического каркаса Воронежской области, оказывающий положительное влияние на биологическое разнообразие и соседних регионов.

\section{Список литературы}

1. Арнольди К.В. 1953. О лесостепных источниках и характере проникновения в степь лесных насекомых при степном лесоразведении. Зоологический журнал, 32 (2): 175-194.

2. Бей-Биенко Г.Я. 1964. Отряд Mantoptera (Mantodea, Mantoidea) - богомоловые. В кн.: Определитель насекомых европейской части СССР. Т. 1. М.-Л., Наука: 170-173.

3. Володченко А.Н. 2010. К познанию фауны ксилобионтных жесткокрылых Хоперского государственного природного заповедника. $B$ кн.: Научные труды Государственного природного заповедника «Присурский». Т. 24. Чебоксары-Атрат, КЛИО: 24-25.

4. Володченко А.Н. 2016. Новые данные по распространению и биологии охраняемых видов жесткокрылых на территории Хоперского заповедника. $B$ кн.: Биоразнообразие и антропогенная трансформация природных экосистем. Материалы Всероссийской научнопрактической конференции, посвященной памяти А.И. Золотухина (г. Балашов, 2-3 июня 2016 г.). Саратов, Саратовский источник: 53-57. 
5. Горшкова В.П., Володченко А.Н. 2015. Структура видовых ассоциаций жуков-усачей (Coleoptera, Cerambycidae) пойменных лесов запада Саратовской области. Поволжский экологический журнал, 4: 381-389.

6. Данилевский М.Л. 2014. Жуки-усачи (Coleoptera, Cerambycoidea) России и соседних стран. Часть 1. Москва, ВШК, 518 с.

7. Ильяшенко В.Ю., Шаталкин А.И., Куваев А.В., Комендатов А.Ю., Бритаев Т.А., Косьян А.Р., Павлов Д.С., Шилин Н.И., Ананьева Н.Б., Туниев Б.С., Семенов Д.В., Сыроечковский Е.Е., Морозов В.В., Мищенко А.Л., Рожнов В.В., Поярков А.Д. 2018. Редкие и находящиеся под угрозой исчезновения животные России. Материалы к Красной книге Российской Федерации. М., Товарищество научных изданий КМК, 112 с.

8. Красная книга Воронежской области. Т. 2. Животные. 2011. Воронеж, МОДЭК, 424 с.

9. Красная книга Воронежской области. Т. 2. Животные. 2018. Воронеж, Центр духовного возрождения Черноземного края, 448 с.

10. Красная книга Российской Федерации. Животные. 2001. Тверь, Астрель, 862 с.

11. Линдеман Г.В. 1964. Заселение стволовыми вредителями лиственных пород в дубравах лесостепи в связи с их ослаблением и отмиранием. $B$ кн.: Защита леса от вредных насекомых. М., Наука: 58-118.

12. Присный А.В. 2003. Экстразональные группировки в фауне наземных насекомых юга Среднерусской возвышенности. Белгород, 296 с.

13. Прокин А.А. 2016. Макрозообентос пойменных озер Хоперского заповедника по данным 2014 г. B кн: Труды Хоперского государственного заповедника. Вып. 10. Воронеж, Научная книга: 234-245.

14. Сажнев А.С., Володченко А.Н., Трушов Д.А. 2018. Предварительные данные по весенней фауне жесткокрылых (Insecta: Coleoptera) памятника природы «Озеро Рассказань» (Саратовская область). Известия Саратовского университета. Новая серия. Серия: Химия. Биология. Экология, 18 (2): 170-178.

15. Nieto A., Alexander K.N.A. 2010. European Red List of Saproxylic Beetles. Luxembourg, Publications Office of the European Union, 45 p.

16. Plewa R., Hilszczański J., Jaworski T., Tarwacki G. 2014. Flower Chafer Protaetia speciosissima (Scopoli, 1786) (Coleoptera: Scarabaeidae): Protected Saproxylic Species of Oak Stands in Poland. Leśne Prace Badawcze, 75 (3): 225-229.

17. Shcherbakov E.O., Savitsky V.Y. 2015. New data on the fauna, taxonomy and ecology of praying mantises (Dictyoptera, Mantodea) from Russia. Entomological Review, 95 (2): 181-199.

18. Zieliński D., Schwarz C.J., Ehrmann R. 2018. Evaluation of the expansion of Mantis religiosa (L.) in Polandbased on a questionnaire survey. Animal Biodiversity and Conservation, 41 (2): 275-280.

\section{References}

1. Arnol'di K.V. 1953. O lesostepnykh istochnikakh i kharaktere proniknoveniya v step' lesnykh nasekomykh pri stepnom lesorazvedenii [On forest-steppe sources and the nature of penetration of forest insects into the steppe during steppe afforestation]. Zoologicheskiy zhurnal [Russian Journal of Zoology], 32 (2): 175-194.

2. Bey-Bienko G.Ya. 1964. Otryad Mantoptera (Mantodea, Mantoidea) - bogomolovyye [Order Mantoptera (Mantodea, Mantoidea) - mantises]. In: Opredelitel' nasekomykh evropeyskoy chasti SSSR [Key to insects of the European part of the USSR]. T. 1. Moscow-Leningrad, Nauka: 170-173.

3. Volodchenko A.N. 2010. K poznaniyu fauny ksilobiontnykh zhestkokrylykh Khoperskogo gosudarstvennogo prirodnogo zapovednika [To the knowledge of the xylobiontic beetle fauna of the Khopersky State Nature Reserve]. In: Nauchnye trudy Gosudarstvennogo prirodnogo zapovednika "Prisurskiy" [Scientific works of the State Nature Reserve "Prisursky"]. T. 24. Cheboksary-Atrat, KLIO: $24-25$.

4. Volodchenko A.N. 2016. Novyye dannyye po rasprostraneniyu i biologii okhranyayemykh vidov zhestkokrylykh na territorii Khoperskogo zapovednika [New data on the distribution and biology of protected beetles in Khopyor Nature Reserve]. In: Bioraznoobrazie i antropogennaya transformaciya prirodnyh ekosistem [Biodiversity and anthropogenic transformation of natural ecosystems]. Materials of the All-Russian scientific-practical conference dedicated to the memory of A.I. Zolotukhin (Balashov, 2-3 June 2016). Saratov, Saratovskij istochnik: 53-57. 
5. Gorshkova V.P., Volodchenko A.N. 2015. Specific assemblage structure of longhorn beetles (Coleoptera, Cerambycidae) in flood-plain forests of the western Saratov region. Povolzhskiy Journal of Ecology, 4: 381-389. (in Russian)

6. Danilevskij M.L. 2014. Zhuki-usachi (Coleoptera, Cerambycoidea) Rossii i sosednikh stran [Longihorn beetles (Coleoptera, Cerambycoidea) of Russia and adjacent countries]. P. 1. Moscow, HSC, $518 \mathrm{p}$.

7. Il'yashenko V.Yu., Shatalkin A.I., Kuvaev A.V., Komendatov A.Yu., Britaev T.A., Kos'yan A.R., Pavlov D.S., Shilin N.I., Anan'eva N.B., Tuniev B.S., Semenov D.V., Syroechkovskiy E.E., Morozov V.V., Mishchenko A.L., Rozhnov V.V., Poyarkov A.D. 2018. Redkie i nakhodyashchiesya pod ugrozoy ischeznoveniya zhivotnye Rossii. Materialy k Krasnoy knige Rossiyskoy Federatsii [Rare and endangered animals of Russia. Materials for the Red Book of the Russian Federation]. Moscow, Tovarishchestvo nauchnykh izdaniy KMK, $112 \mathrm{p}$.

8. Krasnaya kniga Voronezhskoy oblasti. T. 2. Zhivotnye [Red Book of the Voronezh region. T. 2. Animals]. 2011. Voronezh, MODEK, $424 \mathrm{c}$.

9. Krasnaya kniga Voronezhskoj oblasti. T. 2. Zhivotnye [Red Book of the Voronezh region. T. 2. Animals]. 2018. Voronezh, Centr duhovnogo vozrozhdeniya Chernozemnogo kraya, 448 p.

10. Krasnaya kniga Rossijskoj Federacii. Zhivotnye [Red Book of the Russian Federation. Animals]. 2001. Tver, Astrel', 862 p.

11. Lindeman G.V. 1964. Zaseleniye stvolovymi vreditelyami listvennykh porod v dubravakh lesostepi v svyazi s ikh oslableniyem i otmiraniyem [Population of hardwood pests in oak forests of the forest-steppe due to their weakening and extinction]. In: Zashchita lesa ot vrednykh nasekomykh [Protecting the Forest from Pests]. Moscow, Nauka: 58-118.

12. Prisniy A.V. 2003. Ekstrazonal'nye gruppirovki v faune nazemnykh nasekomykh yuga Srednerusskoy vozvyshennosti [Extrazonal groupings in the fauna of terrestrial insects in the south of the Central Russian Upland]. Belgorod, 296 p.

13. Prokin A.A. 2016. Makrozoobentos poymennykh ozer Khoperskogo zapovednika po dannym 2014 g. [Macrozoobenthos of floodplain lakes of the Khopersky Reserve according to 2014]. In: Trudy Khoperskogo gosudarstvennogo zapovednika [Proceedings of the Khopersky State Reserve]. Vol. 10. Voronezh, Nauchnaya kniga: 234-245.

14. Sazhnev A.S., Volodchenko A.N., Truchov D.A. 2018. Preliminary data on the spring fauna of the beetles (Insecta: Coleoptera) of the Razkazan Lake nature monument. Izvestiya of Saratov University. New Series. Series: Chemistry. Biology. Ecology, 18 (2): 170-178. (in Russian)

15. Nieto A., Alexander K.N.A. 2010. European Red List of Saproxylic Beetles. Luxembourg, Publications Office of the European Union, $45 \mathrm{p}$.

16. Plewa R., Hilszczański J., Jaworski T., Tarwacki G. 2014. Flower Chafer Protaetia speciosissima (Scopoli, 1786) (Coleoptera: Scarabaeidae): Protected Saproxylic Species of Oak Stands in Poland. Leśne Prace Badawcze, 75 (3): 225-229.

17. Shcherbakov E.O., Savitsky V.Y. 2015. New data on the fauna, taxonomy and ecology of praying mantises (Dictyoptera, Mantodea) from Russia. Entomological Review, 95 (2): 181-199.

18. Zieliński D., Schwarz C.J., Ehrmann R. 2018. Evaluation of the expansion of Mantis religiosa (L.) in Polandbased on a questionnaire survey. Animal Biodiversity and Conservation, 41 (2): 275-280.

Поступила в редакичюю 27.01.2020

\section{Ссылка для цитирования статьи For citation}

Володченко А.Н. 2020. Новые находки редких насекомых в северо-восточной части Воронежской области. Полевой журнал биолога, 2 (1): 34-43. DOI: 10.18413/2658-3453-2020-2-34-43

Volodchenko A.N. 2020.New Records of Rare Insects in the North-Eastern Part of Voronezh Oblast. Field Biologist Journal, 2 (1): 34-43. DOI: 10.18413/2658-3453-2020-2-34-43 